\title{
Strategy for Improving Quality of Basic Health Services In Selayar Regency
}

\author{
Dedy Herianto ${ }^{1}$ dan Syaharuddin ${ }^{2}$ \\ Departemen Ilmu Pemerintahan, Universitas Pancasakti \\ E-mail: dedyherianto@unpacti.ac.id \\ Email: syaharuddin@unpacti.ac.id
}

(Received: October 24-2020; revised: November 24-2020; published: December 31-2020)

\begin{abstract}
Various efforts in improving the quality of life of public health carried out by local governments have not been effective. The quality of health services in the islands of Selayar Regency is constrained by problems of access, the number of health workers and health facilities. This research method consists of the design of this study using qualitative designs. Data collection was carried out by the method of observation, interviews and documentation. Informants included officials and employees of the health department, health workers at the puskesmas, and the community. Data analysis consists of data reduction, data presentation and drawing conclusions. The results showed that in accordance with the three elements of the strategy dimension, namely objectives, policies, and programs, it could be categorized that the strategy to improve the quality of basic health services in the Selayar regency islands identified was strategy as a plan. Because the strategy as a plan has two basic characteristics, namely to accelerate the actions they will implement to implement programs to improve the quality of basic health services through the Regional Health System policy. And, develop consciously and full of purpose. One of them is by increasing the number of human resources for medical, non-medical and support staff. In addition to improving the quality of health facilities at the primary level (Community Health centers) and trying to maintain the availability of medicines at the health facilities. The problem that is still difficult to overcome is the accessibility of referral health services for people living in the outer islands of Selayar Regency.
\end{abstract}

Keywords: Strategy, Improvement, Service, Health.

\section{INTRODUCTION}

Public service is one of the government's obligations in governance, where the community is the target group for government policies and services. In the perspective of new public management, the public as citizens is the basis (Denhardt and Denhardt, 2009). The government, which is a public organization, is a service provider to the public. Therefore, in order to improve service quality and gain public trust, the government no longer places itself as a government centered in providing public services. This often results in public dissatisfaction in obtaining services, therefore public services by a centralized government need to change to become public oriented.

Public service in the health sector, which aims to improve the quality of human life is one of the government's priority agenda (NAWA CITA). The focus of health development in the 2015-2019 period as stated by the Ministry of Health (2015) is the Healthy Indonesia Program which aims to improve the health status and nutritional status of the community through various efforts in the health sector and community empowerment in order to achieve equal distribution of 


\section{Jurnal Ilmiah Ilmu Administrasi Publik: Jurnal Pemikiran dan Penelitian Administrasi Publik \\ Volume 10 Number 2, July-December 2020. Page 489-495}

health services. Therefore, to achieve increased and equitable access to health services, what needs to be done is the provision of adequate numbers of health workers, types and quality of health workers. Various efforts to improve the quality of human life by formulating various policies that are promotive, preventive and curative in the health sector and the target is the people who live in the archipelago. However, in the end the various government efforts have not been effective. Based on the findings, generally the quality of health services in the coastal areas of the archipelago in various provinces in Indonesia is constrained by problems of access, the number of health workers and health facilities.

Based on data from the Health profile of South Sulawesi Province in 2016, in Selayar Archipelago District the percentage of Healthy Homes was only $49.68 \%$ or 17,540 of the total population of 35,307 houses. When compared to districts / cities in South Sulawesi Province, the percentage of healthy homes in this district is low.

In addition, other basic health data, such as proper sanitation facilities for residents, also show that basic health in the district has not been distributed evenly among the population. This is indicated by the percentage of the population with access to proper sanitation in Selayar Islands district, amounting to 80,669 people or $61.96 \%$ of the total population of 130,199 people. (South Sulawesi Provincial Health Profile, 2016). Based on the description above, the urgency of basic health problems, especially for residents living in archipelagic areas in the two districts, is related to access to basic health services. Meanwhile, basic health is a basic need of society that must be fulfilled by the government. So far, the efforts and strategies undertaken by local governments through various policies and programs have not had a significant impact on improving the quality of basic health services. Therefore, efforts are needed starting with the formulation of the right strategy in order to solve these problems.

Referring to the definition of strategy according to Mintzberg et al (2003), there are five types, including strategy as a plan, strategy as a tactic, strategy as a pattern, strategy as a position, and strategy as a perspective. The five can be viewed from three elements in the strategic dimension, including objectives, policies and programs. Moreover, the phenomena that occur imply a number of strategies are not being implemented optimally.

With regard to the strategy dimension, analyzes of diplomatic military strategy and similar analogies in other fields provide some important insights into the basic dimensions, nature, and design of formal strategies (Mintzberg et al, 2003):

First, an effective formal strategy contains three important elements, namely: a) the most important goals or objectives to be achieved. Goals are one of the dimensions that can create a strategy because goal setting is closely related to the strategy that an organization or agency will use in achieving its goals, where when the goals have been set, we can know which strategy to use; b) the most significant policies guiding or limiting action. Policies are made to determine the direction of a set goal so that policy making makes it easier to direct an organization or agency in implementing a strategy; c) the main sequence of actions (or programs) to achieve the goals set with defined limits. Since strategy determines the overall direction and focus of an organization's actions, formulation cannot be considered as the alignment of objectives to find a predetermined program. Goal development is an integral part of strategy formulation. The program is intended to regulate all actions to be taken so that the strategies to be implemented can be maximally implemented. 
Second, an effective strategy develops multiple concepts and goals to provide cohesion, balance, and focus. Some goals are temporary, others are carried out until the strategy ends. Some costs are more per unit profitable than others. However, resources must be allocated in a pattern that provides sufficient resources to drive success regardless of the relative cost / benefit ratio. As well, organizational units must be coordinated and actions controlled to support the overall pattern of strategic objectives.

Third, strategy deals not only with unpredictability but also with ignorance. For large corporate strategy, no analyst can predict the way in which all forces interact with each other, either by natural or human emotions, or modified by the imagination and intelligent goals of opponents (Mintzberg et al, 2003: 15).

Fourth, only an organization such as the military has multiple echelons of grand, theater, area, combat, infantry, and artillery strategies, so other complex organizations must have a number of hierarchical strategies linked to and mutually supporting. Each of these strategies must be more or less complete in itself, congruent with the degree of decentralization intended. Yet each strategy must be formed as a cohesive between all the major organizational strategies that will be the task of the chief executive officer, that there is a systematic means to test each component strategy and see that it meets the main principles of the strategy formed. (Minztberg et all, 2003).

Mintzberg et al (2003: 3) explain five strategy definitions, namely: a) strategy as a plan which includes actions, guidelines (or defined guidelines) to deal with situations. Strategies have two basic properties, namely they are created to accelerate the action they will implement. As well as, develop consciously and with purpose; b) strategy as a tactic, strategy takes us into the realm of direct competition, where threats, feints, and various other maneuvers work to gain an advantage. This strategy has a strategy formation process in the most dynamic of settings, with provoking movements and beyond. Unfortunately, strategy itself is a concept rooted not in change but in stability to set plans and patterns; c) strategy as a pattern where there are three proposed definitions of strategy as a pattern in the sequence of actions (Mintzberg and Waters, 1985), strategy is behavior (Henry Ford), and strategy is the consistency of behavior, whether it is intended or not (in Mintzberg et al. : 2003); d) strategy as a position where the organization is placed in the world where the organization is called the environment; e) strategy as a perspective or viewpoint is content which consists not only of choosing a position, but a way of understanding the world. All strategic concepts have one important implication, that all strategies are abstractions that only exist in the minds of interested parties. Nobody has ever seen or touched strategy, every strategy is an invention, the fantasy of one's imagination, whether formulated as an intention to regulate behavior or inferred as a pattern to describe existing behavior.

With regard to strategies for improving the quality of basic health, it is known that health services are dynamic activities in the form of helping to prepare, provide and process and assist the needs of others. Health service is every effort that is carried out individually or jointly in an organization to maintain, improve health, prevent and cure diseases and restore health of individuals, families, groups and / or communities.

The Health Office and other offices as Regional Work Units (SKPD) have the function of realizing health service effort institutions for the community. The Health Office has the task of carrying out the authority of Regional Government and assistance in the health sector. The Health Office plays a role in technical policy formulation, implementation and control, guidance and licensing in the health sector which includes: a) Disease control and environmental health; b) 


\section{Jurnal Ilmiah Ilmu Administrasi Publik: Jurnal Pemikiran dan Penelitian Administrasi Publik \\ Volume 10 Number 2, July-December 2020. Page 489-495}

Health Service Sector; c) The field of health promotion and family health; and d) Facilities and infrastructure and health information.

\section{METHODS}

\section{Research Approach}

The research approach uses a qualitative approach, namely research that intends to understand the phenomenon of what the research subjects experience holistically, and by means of descriptions in the form of words and language, in a special natural context and by utilizing various scientific methods (Moleong, 2007). : 6). This study also intends to find out or describe the reality of the events under study so that it makes it easier for the authors to obtain objective data in order to know and understand the Strategy for Improving the Quality of Basic Health Services in the Islands Region of Selayar Regency.

\section{Research Design}

Research design is a flow or stage in conducting research. In this study, the approach used is a qualitative approach, so the research design in this study consists of three stages, namely: the preparation stage, the planning stage, the field research stage, and the research reporting stage. The preparatory stage concerns the study and determination of research problem issues. The planning stage involves the preparation of a research proposal on the basis of research issues. The field research stage involves collecting research data using research instruments, namely interview guidelines, observation guidelines, and document review guidelines. The last stage is research reporting concerning the preparation of research reports by analyzing research data with the qualitative analysis stage. The research design flowchart is as shown in the chart below:

Figure 2

Research Design Flowchart

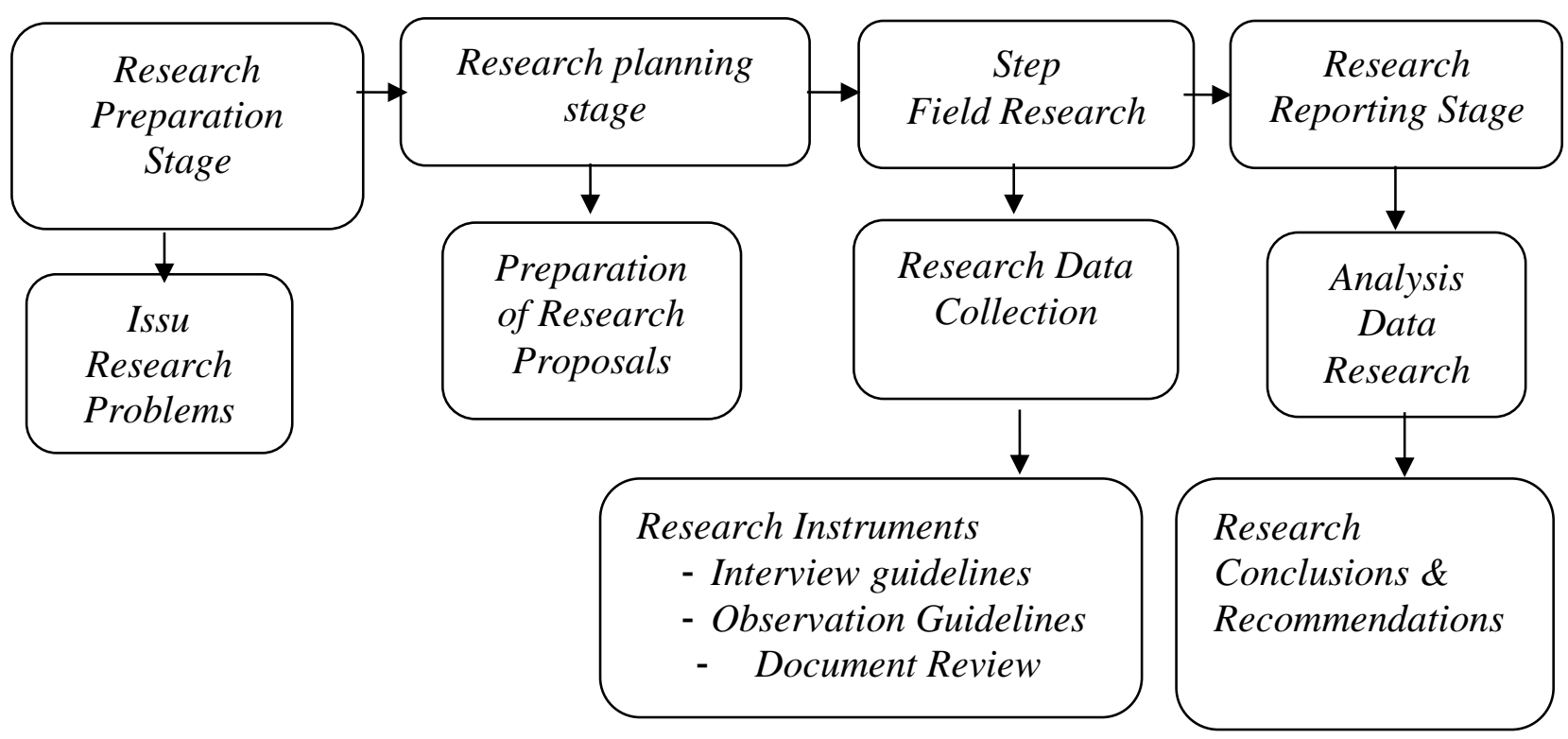


There are two sources of data in this study, namely primary and secondary data. Primary data is primary data derived from original sources and collected specifically to answer research questions. Therefore, researchers conducted direct interviews with informants. The informants in this study are people who are involved and in the focus of this research, both from the policy implementer and the community as the target of the policy. The informants included: a) Head of Health Service; b) Health Service staff; c) Health Workers; d) hospital staff; e) People who live in the archipelago. While secondary data is data obtained through other parties, data obtained by researchers who are not directly from the subject of their research are usually documents or other reports.

\section{Data Collection Techniques and Instruments}

Data collection techniques consisted of in-depth interviews, observation, and documentation. Observation is a method that focuses on direct observation at the research location in order to see and know for sure about the Service Quality Improvement Strategy. Basic Health. Interviews are direct oral question and answer activities, interviews are carried out in order to obtain information relevant to the research objectives. Document review, namely reviewing documents in the form of reference books and regulations or articles related to this research in order to complement the materials related to the research that the author conducted.

\section{Data Processing Techniques and Data Analysis}

The data analysis process is carried out continuously, starting with reviewing all available data from various sources, namely from interviews, observations that have been written in field notes, documents and so on to drawing conclusions. In conducting data analysis, the researcher refers to several stages using exploratory analysis, which is to reveal the phenomena that occur in depth and systematically. In this study, data analysis was carried out by combining the results of the interviews. Then, the final results of the conclusions are summarized as a whole so that the summary and final report will describe the Strategy for Improving the Quality of Basic Health Services in the Selayar Regency Islands area.

\section{RESULT AND DISCUSSION}

To explain the results of research based on strategy theory, there are five types, including strategy as a plan, strategy as a tactic, strategy as a pattern, strategy as a position, and strategy as a perspective. The five can be viewed from three elements in the strategic dimension, including objectives, policies and programs.

The first element is the objective of the related institutions or agencies, in this case the Selayar District Health Office, which has the main objective of Improving Health Quality, especially basic health for people who live in the archipelago as a solution to solving problems at the level of public health. Then it is hoped that there will be equal distribution of affordable and quality health efforts. Another goal to be achieved in Health Quality Improvement is to increase public awareness to maintain their health by taking preventive measures rather than treating diseases. This is important because of the limitations and access to health facilities in the archipelago, which is far from the district capital which is on the main island. 


\section{4 | Jurnal Ilmiah Ilmu Administrasi Publik: Jurnal Pemikiran dan Penelitian Administrasi Publik \\ Volume 10 Number 2, July-December 2020. Page 489-495}

The second element is a government policy or regulation that regulates it to be achieved in accordance with the objectives. The policies are made in the form of the Regional Regulation of the Selayar Islands Regency Number 2 of 2014 concerning the Regional Health System. The scope of this policy includes health efforts, health financing, health human resources, provision of pharmaceuticals, medical devices and community empowerment. The implementation of the policy in the form of a Regional Regulation is carried out by the Health Office as the leading sector in charge of all primary health facilities including puskesmas and posyandu together with K.H Hayyung Regional General Hospital as secondary level health facilities. The governmentowned health facilities consist of 1 Regional General Hospital, 14 health centers, and 289 posyandu. In addition, this policy also involves private health facilities in providing quality health services to the public. To support the implementation of the Regional Health System, it was instructed also to all 264 health workers in each district and 33 doctors to comply with the policy.

The last element is the program, as a form of action to achieve goals with set limits. Therefore, technical implementing organizations, in this case the Health Office as the leading sector, carry out various programs to support the implementation of the Regional Health System such as adding health personnel, providing medicines, providing medical devices, building health infrastructure involving the Public Works Office, community nutrition improvement programs, preventive programs such as health socialization and promotion for the prevention and eradication of infectious diseases, maternal and child health programs and family planning in collaboration with the National Population and Family Planning Board, environmental health improvement programs. In addition, the community empowerment program in the health sector is also one of the routine programs carried out by the Selayar District government through the Health Office and other stakeholders.

This study shows that the identified basic health quality improvement strategy is a strategy as a plan. Strategy as a plan as proposed by (Minztberg et al: 2003) has two basic characteristics. First, accelerate the actions they will implement. The Regional Health System Policy of the Selayar archipelago district government implemented by the Health Office, Regional General Hospital or equivalent, health facilities such as puskesmas and posyandu and other stakeholders is one of the government's efforts in the form of regional regulations to improve the quality of basic public health. Because the target object of the policy is the community, all stakeholders together with the community support and contribute to the policy being successful in achieving the stated objectives. Community involvement in the form of empowerment activities oriented towards improving the quality of health.

The second characteristic is developing consciously and purposefully. Improving the quality of basic health through the Regional Health System policy is carried out in accordance with the urgency of the birth of the policy. Therefore, to achieve the goal, various ways need to be done by the local government of Selayar district, in this case the Health Office as the leading sector responsible conceptually and technically for implementation.

Based on the results of the study, the identification of a strategy as a plan as a strategy used by the Selayar archipelago district government shows that this strategy determines the overall direction and focus of the Health Office's actions and the alignment of various objectives to produce adopted programs. Goal development is an integral part of strategy formulation. The 
program is intended to regulate all actions to be taken so that the strategy for improving the quality of basic health that will be implemented can be implemented optimally.

\section{CONCLUSIONS}

Based on the results of the discussion, it can be concluded that the identified strategy for improving the quality of basic health is a strategy as a plan. The implementation of strategies for improving the quality of basic health is considered very useful and effective in dealing with health problems in the Selayar Islands Regency. This is because the strategy as a plan has two basic characteristics, namely to accelerate the actions they will implement to implement the Regional Health System policy as an effort to improve the quality of basic health. Then develop consciously and purposefully.

\section{REFERENCE}

Calnan, M., Rowe, R. 2006. Researching trust relation in health care : Conceptual and. Fred R.David. 2006. Manajemen Strategi, Edisi ke-10, Jakarta: Salemba Empat.

Frederickson, G.H. 1997. The Spirit of Public Administration. San Francisco : Jossey Bass

Hacker, J. 2004. Privatizing Risk without Privatizing the Welfare State : The hidden Politics of social policy retrenchment in United Stated. American Political Science Review. Vol 98 (2) : 243-260

Hosmer, L.T. 1995. Trust : The Connecting link between organizational theory and philosophical ethic. Academic Management and Administration. Vol. 20 (2) : 379 403.

Irvin, R.A.,Stansbury, J. 2004. Citizen participation in decision-making : Is it worth the effort ?. Public Administration Review. Vol 64 (1) : 55-65

King, C.S.,Feltey, K.M.,Susel, B. O. 1998. The question of participation : Toward authentic public participation in public administration. Public Administration Review. Vol. 48 (4) 317-326.

Moleong, J. 2009. Metode Penelitian Kualitatif, bandung : Rosdakarya

Mintzberg, Henry, Lampel, Joseph, Quinn, James Brain, dan Sumantra Ghoshal. 2003. The Strategy Process, New Jersey: Pearson Education..

Profil Kesehatan Provinsi Sulawesi Selatan Tahun 2016.

Siswati, Sri. 2015. Kualitas Pelayanan Kesehatan Dengan Kepuasan Pasien Bpjs Di Unit Rawat Inap RSUD Kota Makassar. Jurnal Media Kesehatan Masyarakat Indonesia (MKMI). Vol 11 (3) : 174-183. 